\title{
Effectiveness Of Online Service System In The Office Of National Land Agency Of Semarang City
}

\author{
Delvi Amalia Rosa ${ }^{1}$, Gunarto ${ }^{2}$ and Aryani Witasari ${ }^{3}$
}

\begin{abstract}
The research of "Effectiveness of Online Service System at Land Office of Semarang" aims to determine how the effectiveness of online services in the Land Office of Semarang, determine the impact and solutions online services in the Office of the National Land Agency of Semarang.

The method used in this paper is the specification method of sociological judicial collecting data to obtain data that will be used as the contents of a journal through interviews with officials of the National Land Agency of Semarang or by observing the object to obtain data. Then it will be carried out analysis of data obtained from various sources.

The results showed that the use of systems-based services online have efficacy and good effect because it allows officers to check the lack of service the Land Office of Semarang, while the various obstacles that arise regarding the use of services of National Land Agency online, but all obstacles superbly gain solution. Both solutions have been realized and those still in the proposal.

Keywords: Effectiveness; Service; National Land Agency
\end{abstract}

\section{Introduction}

Land within the territory of the Republic of Indonesia is one of the main natural resources, in addition to having the value of deep inner to the people of Indonesia, it also serves a very strategic in meeting the needs of the country and the people are more diverse and increased both the national level and in relation to international level. ${ }^{4}$ Although the land is an asset that is difficult management and land assets of the region are manifold with the status of use also vary, causing a lot of interest, the state must ensure the rights on land granted to citizens in accordance with the law to be used and taken advantage. As stipulated in the Basic Agrarian Act No. 5 of 1960 Article 16, the rights in question include the Properties, Broking, Right to Use Rights Lease and other rights included in the rights of temporary. ${ }^{5}$

In Article 33 paragraph (3) of the 1945 Constitution states "Earth, water and natural resources contained therein is controlled by the state and used prosperity of the people."6

The importance of land uses for human life then the intervention of the state through its agents in the order of the land law is an absolute must. ${ }^{7}$ Registration of land is very important in order to achieve the orderly administration of land, know the status, land area, land boundaries, buildings thereon and plants that are above the ground and on the registration of land belonging to us, we will obtain legal protection and legal

1 Studens Master of Notary Law, Sultan Agung Islamic University Semarang email delviar.delviar@gmail.com

${ }^{2}$ Faculty of Law Unissula, Semarang.

3 Faculty of Law Unissula, Semarang.

"Boedi Harsono, 2003, "Menuju Penyempurnaan Hukum Tanah Nasional", Jakarta : Universitas Trisakti, p.3

${ }^{5}$ Act No. 5 of 1960 on Agrarian

${ }^{6}$ Republic of Indonesia Act of 1945

${ }^{7}$ Hambali Thalib. 2009. "Sanksi Pemidanaan Dalam Konflik Pertanahan; Kebijakan Alternatif

Penyelesaian Konflik Pertanahan Di Luar Kodifikasi Hukum Pidana". Jakarta : Kencana, p.1 
certainty as well as getting proof of ownership of the land in the form of a certificate. A certificate is proof of land rights. ${ }^{8}$

Regarding the registration of land has been set on a legal basis, namely Act No. 5 of 1960 About the Basic Regulation of Agrarian. And as a legal guarantee contained in Article 19 of the Basic Agrarian Law on Land Registration, Government Regulation No. 24 of 1997 on Land Registration; PMA or Head of BPN No. 3 of 1997 on the implementation of PP No. 24 of 1997 on Land Registration.

The National Land Agency, hereinafter referred to as BPN is a government agency that has the task of carrying out non-ministry government tasks in the area of land in accordance with the legislation. According to the Presidential Regulation No. 20 Of 2015 concerning the National Land Agency Article 1 (1) explains that the National Land Agency later shortened non-ministry BPN is a government institution under and responsible to the President. ${ }^{9}$

BPN services there is still done manually, and therefore the time required for the service is also very limited. The process of the search data of the request is also done manually when the data is only stored in the archives of the simple form of a paper prepared by neighborhood respectively. Another constraint is to access more information about the data the applicant and land information. Public perception on this matter that is of service in the land sector the procedure is still difficult, time consuming and high costs. This shows the necessity people demands openness in the implementation of the procedure as well as the certainty of the time and costs to be incurred by the public. The uncertainty this time had a huge impact on PPAT (Land Deed Official) due to wastage of time and cause all pending activities.

Rapid technological developments bring progress in almost all aspects of human life. ${ }^{10}$ More and more people today are required to master the Internet technologies to simplify, accelerate and expand the network for any job or any of their activities. But do not close the possibility of human error or system error that will have an impact and influence on the results of their performance which is still classified as a beginner to use Internet technology.

To clarify the issues to be discussed anything what it is imperative to formulate the problem. The formulation of the problem to be addressed is how the effectiveness of the online service system at the Land Office of Semarang and what challenges and solutions online service system in the office of the National Land Agency of Semarang?

\section{Research methods}

The method used by the authors is sociological juridical means a study of the real state of society or community environment with the intent and purpose of finding facts, which then leads to the identification, and ultimately lead to the settlement of the problem. This method is carried out to find the relationship between the data collection tool that consists of the study of documents, observation and interview.

Specification used in this study is a descriptive study, the research done by the depiction of the realities that exist or activities carried out by the object. Descriptive research aims to provide a snapshot of a situation as carefully as possible about the symptoms of an individual or certain groups.

\footnotetext{
${ }^{8}$ Government Regulation No. 24 of 1997 on Land Registration

${ }^{9}$ Government Regulation No. 20 of 2015 concerning the National Land Agency

${ }^{10}$ Man Suparman Sastrawidjaja. 2002. "Perjanjian Baku dalam Aktivitas Dunia Maya, Cyberlaw :

Suatu Pengantar". Jakarta : Elips, p.14
} 
Volume 6 Issue 2, June 2019

\section{Results and Discussion}

\subsection{The effectiveness of online services in the Land Office of Semarang}

Effectiveness is a term used to measure the achievement of success. The elements of effectiveness include:

a. Punctuality. Time is a very important thing because it cannot go back. Time really affect the level of success and failure of an organization. Therefore, it is necessary to use the maximum time to achieve effectiveness.

b. The accuracy of calculation of the cost. Cost is something very important in the implementation of activities, costs also affect the smooth running of an organization's activities. Lack of funding or fee amount can inhibit the activities of the organization, so it can lead to ineffectiveness.

c. The accuracy of the measurement. Each activity certainly has the size, in order to determine the support portion to be used, therefore the need for accuracy in the measurement in order to create effective.

d. The accuracy in determining the choice. Errors in choosing a job, methods, objects, friends, couples and others is a picture of ineffectiveness as well as the possibility of creating regret later. On the contrary that the accuracy choose will provide happiness for man in question in the course of his life.

e. The precision of thought. The precision thinking of various aspects of life with regard to himself and the universe that continues to provide its influence positively and negatively.

f. Accuracy in performing the command. The success of an organization's activities are very much influenced by the ability of a leader, one of the demands the ability to give clear instructions and easy to understand by subordinates. If the command is given to subordinates who can not understand or be understood, then the implementation of the command can be understood, or understood, then the implementation of the command can be certain to experience difficulties and even failures in its implementation and will ultimately harm the organization concerned.

g. The accuracy in determining the destination. Any form of organization is always to achieve the goals they have agreed in advance and usually always agreed set forth in a written document that is more strategic so that it can serve as guidelines in the implementation of activities.

h. The accuracy of targeting accuracy. Line what we have said above that the aim is more oriented to the long-term and strategic in nature, while the target is more oriented to the short term and a more operational nature, targeting the right kind established by individuals or organizations actually determine the success of the organization's activities.

Implementation of regional autonomy provide an opportunity for local governments to manage their own areas. Since the regional autonomy, public service continues to be the talk is relentless because public service is one variable which to measure success or failure of the implementation of regional autonomy in the city due to local autonomy give governments the freedom to create and develop innovation in public services. When a public service goes well it could be said activities of the regional autonomy are also going well.

One of the agencies that implement technology-based innovation and implement a computerized system that the Land Office or the National Land Agency of Semarang. One of them named GEM or Independent Registration of the Land Deed. GEM Services is aimed at ensuring orderly land administration, improve services in the area of land, 
improve the quality of information, simplify data maintenance, archiving, improving human resource capacity, and speed up service.

Application of GEM by the Head of BPN Regulation No. 8 of 2012, on Amendment to the Regulation of the Minister of State for Agrarian Affairs / Head of BPN No. 3 of 1997 on the Provisions Implementing Regulation No. 24 of 1997 on Land Registration, that in order to improve services in the area of land began in 2013 preparation and manufacture of blanks PPAT deed done by each good of PPAT While nor special. The purpose of GEM is to facilitate the working area of the city of Semarang PPAT through online application.

The size of the effectiveness of the online service system can be known through the application of community satisfaction survey. So any service whatsoever in this land can be directly automatically lead to the online application machine that includes how effective online service, any profit uses online services, things whatever, the less good or less satisfactory and others. Service with this online system to augur well for the land office in the city of Semarang. Due to the existence of online applications the user will automatically taken to the page of community satisfaction survey after using the application. Of the community satisfaction survey the land office becomes easier to see and assess what things are not good or what things are less satisfactory.

Based recap report IKM file or Community Satisfaction Index latest Central Java in May 2019 for the Land Office of Semarang in position number 12 out of 35 existing Land Office. In the report, there were 722 files. That means as many as 722 people have used the application of the Land Office of Semarang based online. Then for the conversion of the resulting value is 81.70 and got a good performance category.

\subsection{Obstacles and solutions in the online service of the National Land Agency office in Semarang}

Challenges and solutions of the National Land Agency, among others:

a. Network or server parent who often have impaired errors that cause the cessation of online services.

The solution that the Land Office of Semarang has prepared two (2) backup network that can be used when the main network is being error. However, if the interference is caused by tissue repair of the headquarters of the BPN Semarang will be announced through the speaker and usually this disturbance will be completed on the same day.

b. Traffic web CTF (Computerized Land Office) is often disrupted due to some officers who misuse the internet facility to work but are used to access the personal things that can cause the quality and quantity of jobs to be reduced.

The solution is if there are officers who caught as it will be given a reprimand. Reprimand given also gradually starting from verbal reprimand, a reprimand with a letter or written, or moved to another department.

c. Lack of skills or human resources clerk who was at the land office in using the tools of technology, given that innovation is a new online service is an innovation-based information systems that rely heavily on technology.

The solution is an officer who served in certain parts only in dedicated in part only, no need to take care of the other part. So any existing officers their share so it is definitely understood and mastering duties. There also if officers unfamiliar with the Internet or computers then BPN Semarang already set up IT personnel.

d. The number of computers that are used as a means or facilities applicant still very limited so that the applicant still had megantri and turns in the use of computers. 
The solution is to increase the number of existing computers so employees PPAT are not registered can do so online at BPN Semarang without a long queue.

e. Printing machine or printer in conditions that are less care and attention, causing endless ink but not immediately charged. The paper used to print a document or file is also often depleted and not replenished so that the applicant must bring their own paper required to print a document.

The solution that the Land Office of Semarang has been increasing the number of technicians so small probability happen constraints such as existing technicians who routinely check the state of the printer, the availability of the ink, and paper.

$\mathrm{f}$. The room and the seating also service it is still inadequate, with the volume of people and PPAT who come are not comparable with the capacity of the room so many applicants waiting outside the room.

The solution that has been proposed should follow the example of the city of Surabaya Semarang city that has split the territory. In the case of splitting the region into Semarang 1 and 2 or East Semarang and West Semarang. Because in the examination of the number of applications in Semarang city average of 2000025000 applicant per month while the number of human resources is not an option here. So when BPN Semarang has been split region will add considerable manpower to cope with the large number of applicants.

\section{Closing}

\subsection{Conclution}

Based on what has been described in the previous section, it can be concluded as follows:

1) Service with this online system to augur well for the land office in the city of Semarang. Due to the existence of online applications the user will automatically taken to the page of community satisfaction survey after using the application. Of the community satisfaction survey the land office becomes easier to see and assess what things are not good or what things are unsatisfactory so it can be immediately improved performance.

2) Every constraints experienced there is a solution respectively, as a few examples:

a. Tissue damage and lack of human resources has been handled by a team of IT experts

b. Completeness of computer equipment such as printing presses, ink and paper are already in charge itself

c. The rooms were small and seating is limited because too many applicants already in the proposal to split the region so that all applicants can be served quickly

\subsection{Suggestion}

1) For the National Land Agency in order to improve the effectiveness of the use of online systems in order to be more productive in carrying out the work and can expedite matters other offices that had to do with the land. And to always check the state of any equipment or stationery so no complaints about the endless printing supplies file.

2) To the public, especially the Notary office employees in order to help to urge others to fill out a form to encourage Community Satisfaction Index National Land Agency in order to further enhance the online-based services system 


\section{Bibliography}

[1] Ghozali, Imam, 2007, Aplikasi Analisis Multivariat dengan Program SPSS. Semarang : Universitas Diponegoro

[2] Harsono, Boedi, 2003, Menuju Penyempurnaan Hukum Tanah Nasional. Jakarta : Universitas Trisakti

[3] Indrawijaya, Adam Ibrohim, 2010, Teori, Perilaku dan Budaya Organisasi. Bandung: PT. Refika Aditama

[4] Ismawati, Erni, 2015, Pengaruh Efektivitas Penerapan PERMATA (Pendaftaran Tanah Mandiri Akta Tanah) Terhadap Kualitas Pelayanan Publik di Kantor Pertanahan Kota Semarang. Semarang : Universitas Diponegoro

[5] Sastrawidjaja, Man Suparman, 2002, Perjanjian Baku dalam Aktivitas Dunia Maya, cyberlaw : Suatu Pengantar. Jakarta : Elips

[6] Parlindungan, AP. 1990. Pendaftaran Tanah di Indonesia. Bandung : Mandar Maju

[7] Raymond, McLeod. 2008. Sistem Informasi Manajemen. Jakarta : Salemba Empat

[8] Sinambela, Lijan Poltak dkk. 2006. Reformasi Pelayanan Publik : Teori, Kebijakan dan Implementasi. Jakarta : Bumi Aksara

[9] Syafiie, Inu Kencana. 2006. IImu Administrasi Publik. Jakarta : Rineka Cipta

[10]Thalib, Hambali. 2009. Sanksi Pemidanaan Dalam Konflik Pertanahan : Kebijakan Alternatif Penyelesaian Konflik Pertanahan Di Luar Hukum Pidana. Jakarta : Kencana

[11] Constitution of the Republic of Indonesia of 1945

[12]Act No. 5 of 1960 on Agrarian

[13] Government Regulation No. 24 of 1997 on Land Registration

[14] Government Regulation No. 20 Of 2015 concerning the National Land Agency 